\title{
Cold type autoimmune hemolytic anemia- a rare manifestation of infectious mononucleosis; serum ferritin as an important biomarker
}

Chinthana Dematapitiya ${ }^{1 *}$, Chiara Perera², Wajira Chinthaka', Solith Senanayaka ${ }^{1}$, Deshani Tennakoon', Anfas Ameer ${ }^{1}$, Dinesh Ranasinghe ${ }^{1}$, Ushani Warriyapperuma ${ }^{1}$, Suneth Weerarathna ${ }^{1}$ and Ravindra Satharasinghe ${ }^{1}$

\begin{abstract}
Background: Infectious mononucleosis is one of the main manifestations of Epstein - Barr virus, which is characterized by fever, tonsillar-pharyngitis, lymphadenopathy and atypical lymphocytes. Although $60 \%$ of patients with IMN develop cold type antibodies, clinically significant hemolytic anemia with a high ferritin level is very rare and validity of serum ferritin as an important biomarker has not been used frequently.

Case presentation: 18-year-old girl presented with fever, malaise and sore throat with asymptomatic anemia, generalized lymphadenopathy, splenomegaly and mild hepatitis. Investigations revealed that she had cold type autoimmune hemolysis, significantly elevated serum ferritin, elevated serum lactate dehydrogenase level with serological evidence of recent Epstein Barr infection. She was managed conservatively and her hemoglobin and serum ferritin levels normalized without any intervention following two weeks of the acute infection.

Conclusion: Cold type autoimmune hemolytic anemia is a rare manifestation of infectious mononucleosis and serum ferritin is used very rarely as an important biomarker. Management of cold type anemia is mainly supportive and elevated serum ferritin indicates severe viral disease.
\end{abstract}

Keywords: Infectious mononucleosis (IMN), Hemolytic anemia, Ferritin

\section{Background}

Epstein - Barr virus is one of the most ubiquitous human viruses, infecting more than $95 \%$ the adult population worldwide. Infectious mononucleosis is the main clinical syndrome of Epstein - Barr virus infection; this clinical syndrome is characterized by fever, tonsillar-pharyngitis, lymphadenopathy and atypical lymphocytes.

In cold type autoimmune hemolytic anemia (AIHA) IgM antibodies are formed against the polysaccharide antigens of red blood cells, which cause agglutination in low temperatures leading to complement activation and hemolysis. Cold type AIHA is mainly caused by lymphoid malignancies and rarely it can be caused by infections mainly Mycoplasma pneumoniae and infectious mononucleosis (IMN). Diagnosis of cold type AIHA due to IMN is confirmed by demonstrating red cell aggregates in a peripheral blood smear, presence of high titers of cold antibodies, positive direct antiglobulin test (IgG negative / C3d positive) with serological evidence of recent IMN infection [1].

Although $60 \%$ of patients with IMN develop cold type antibodies, clinically significant hemolytic anemia with a high ferritin level is very rare [2]. There are only few published cases in medical literature; hence we describe a case of clinically significant cold type autoimmune hemolytic anemia associate with significantly high serum ferritin as a rare manifestation of IMN.

\footnotetext{
* Correspondence: chinthanadematapitiya@yahoo.com

${ }^{1}$ Sri Jayawardanapura General Hospital, Thalapathpitiya, Nugegoda, Western province, Sri Lanka

Full list of author information is available at the end of the article
}

(c) The Author(s). 2019 Open Access This article is distributed under the terms of the Creative Commons Attribution 4.0 International License (http://creativecommons.org/licenses/by/4.0/) which permits unrestricted use, distribution, and reproduction in any medium, provided you give appropriate credit to the original author(s) and the source, provide a link to the Creative Commons license, and indicate if changes were made. The Creative Commons Public Domain Dedication waiver (http://creativecommons.org/publicdomain/zero/1.0/) applies to the data made available in this article, unless otherwise stated. 


\section{Case presentation}

Eighteen-year old girl presented to us with sore throat, malaise, fatigue and fever for 10 days. She was apparently well 10 days back where she initially developed a sore throat followed by fever with chills and a non-productive cough. She did not have any abdominal pain, acrocynosis or exertional dyspnea. She did not have any contact history of similar illness.

On examination she was well looking. She was pale but not icteric. Oral examination revealed inflamed tonsils. She had tender, discrete, mobile bilateral anterior and posterior cervical lymph nodes with bilateral inguinal lymphadenopathy. On admission she had fever $\left(39.2^{\circ} \mathrm{C}\right)$ with no evidence of dehydration. She did not have any evidence of peripheral gangrene or acrocynosis She was found to have tachycardia (110 beats/min) with normal blood pressure. Her cardiovascular and respiratory system examinations were unremarkable. Her abdominal examination revealed mild, non-tender splenomegaly with no hepatomegaly.

On admission laboratory testing was remarkable for macrocytic moderate anemia with a hemoglobin of $8.6 \mathrm{~g} / \mathrm{dl}$ (normal $11-16 \mathrm{~g} / \mathrm{dl}$ ), mean corpuscular volume $96.3 \mathrm{fl}$ (normal $80-96 \mathrm{fl}$ ), mean corpuscular hemoglobin $37.7 \mathrm{pg}$ (normal 27-34 pg), red blood cell mass $2.28 \times 10^{6} / \mathrm{ul}$ (normal 3.5-5.5 $\times 10^{6} / \mathrm{ul}$ ), white blood cell count $8.27 \times 10^{3} / \mathrm{ul}$ (normal 4-11 $\times 103$ ), neutrophils $48.4 \%$ and lymphocytes $45.9 \%$. Her blood pictures revealed macrocytes, spherocytes, few polychromatics and lymphocytosis with atypical lymphocytes. Her direct anti globulin test (DAT) was positive and DAT profile revealed positive for C3d and negative for IgG. Her monospot test was positive and Epstein Barr virus (IgM) antibody was positive as well (EBV- viral capsid antigen (VCA)- IgM using ELISA method was positive but IgG was negative). Her biochemical tests revealed serum ferritin $>1650 \mathrm{ng} / \mathrm{ml}(6.9-282.5 \mathrm{ng} / \mathrm{ml})$, serum iron $12.6 \mu \mathrm{mol} /$ 1 (normal $5-33 \mu \mathrm{mol} / \mathrm{l}$ ), total iron binding capacity (TIBC) 50.1 (normal 52.0-101.0), transferrin saturation 25.15\%, serum lactate dehydrogenase (LDH) 1673u/l (normal 200-400u/l), serum heptoglobulin <9 mg/dl (normal 30$200 \mathrm{mg} / \mathrm{dl}$ ), Aspartate transaminase (AST) 124.5u/l (normal 0-31u/l), Alanine transferase (ALT) 46.7u/l (normal 7-35u/l), total bilirubin $1.3 \mathrm{mg} / \mathrm{dl}($ normal $0.3-1.20$ ) with an increased indirect fraction, alkaline phosphatase $77.4 \mathrm{u} / 1$ (normal 30$120 \mathrm{u} / \mathrm{l}$ ), serum creatinine $41.1 \mu \mathrm{mol} / \mathrm{l}$ (normal $0-97 \mu \mathrm{mol} / \mathrm{l}$ ), C reactive protein $24 \mathrm{mg} / \mathrm{l}$ (normal $<6.0 \mathrm{mg} / \mathrm{l}$ ), erythrocyte sediment rate $60 \mathrm{~mm} /$ hour (normal $0-10 \mathrm{~mm} /$ hour). Her anti-nuclear antibodies and rheumatoid factor was negative. Her ultrasound scan abdomen showed mild splenomegaly $(11.3 \mathrm{~cm} \times 6.0 \mathrm{~cm})$ and transthoracic echocardiogram was normal.

She was given analgesics and advised to bed rest and avoid cold exposure and started on folic acid $5 \mathrm{mg}$ daily. Since she was clinically not symptomatic for anemia, blood transfusion was not done. After 3 weeks her hemoglobin rose up to $10 \mathrm{~g} / \mathrm{dl}$ and serum ferritin level reduced to $925 \mathrm{ng} / \mathrm{ml}$ and after six weeks follow up there was no lymphadenopathy on examination, her hemoglobin rose up to $11.5 \mathrm{~g} / \mathrm{dl}$, serum ferritin level normalized to $250 \mathrm{ng} / \mathrm{ml}$ and the repeat (VCA) - IgM was negative but (VCA)-IgG became positive.

\section{Discussion and conclusions}

Cold type autoimmune hemolytic anemia (AIHA) is a rare manifestation of infectious mononucleosis (IMN) and serum ferritin is used very rarely as an important biomarker. In this case our patient had cold type AIHA, significantly high levels of serum ferritin with hepatitis and splenomegaly, high levels of lactate dehydrogenase (LDH) with fever and generalized lymphadenopathy caused by infectious mononucleosis.

The exact pathogenesis of IMN causing cold type AIHA is poorly understood. But according to suggested mechanisms initially there is formation of IgM antibodies to EBV. Then due to the molecular mimicry, IgM antibodies cross react with $\mathrm{RBC}$ polysaccharide antigens and result in formation of antigen-antibody complexes. This will activate the complement $(\mathrm{C} 1)$ complex. Then it will activate $\mathrm{C} 4 / \mathrm{C} 2$ complex forming $\mathrm{C} 3$ convertase, which produces $\mathrm{C} 3 \mathrm{~b}$, which will deposit on the $\mathrm{RBC}$ membrane. In cold temperatures, when IgM is bound to the antigen, $\mathrm{C} 3 \mathrm{~b}$ will activate $\mathrm{C} 5$, forming membrane attack complexes, which will eventually cause intravascular hemolysis. But upon warming, IgM antibody dissociates from the $\mathrm{RBC}$ membrane but $\mathrm{C} 3 \mathrm{~b}$ will remain attached to RBC surface. Those RBC will be eventually destroyed in the reticulo-endothelial system, mainly spleen and causes extravascular hemolysis [3]. In our patient hemolysis was confirmed by an increased total bilirubin with a high indirect fraction, increased LDH and decrease level of heptoglobulin. Since direct antiglobulin test (DAT) became positive with DAT profile revealing positive C3b with a negative IgG, we confirmed she had cold type - autoimmune hemolytic anemia. Interestingly our patient did not have clinical acrocyanosis, so may be the extravascular hemolysis was predominant in her causing the moderate anemia.

In this case she had significantly high levels of serum ferritin with mild hepatitis and mild splenomegaly. Causes for her high serum ferritin may be multifactorial. It can be due to acute phase response following Epstein Barr infection. In our patient there was mild elevation of $C$ reactive protein (CRP) but very high levels of serum ferritin. It has been shown that although classical inflammatory parameters such as CRP have proven its usefulness in bacterial or fungal infections, when it comes to viral infection CRP often has very low sensitivity and is non-discriminatory. It has also shown that during an acute Epstein Barr virus (EBV) infection there will be a rise in serum ferritin as an acute phase reactant and the 
ferritin level will rise according to the disease severity along with interleukin 8, whereas in most acute EBV infections CRP will be non-specific and will be below the detected level. This shows, although CRP and ferritin both are acute phase reactants formation of them involve two separate inflammatory pathways [4]. High serum ferritin also can be due to a chronic hemolytic anemia. Barbec $\mathrm{V}$ et.al has done measurements of serum ferritin levels of 121 patients who have been diagnosed to have various chronic hemolytic disorders and it has shown that there is a moderate rise in serum ferritin levels in autoimmune hemolytic anemia and the range of serum ferritin value is associated with the degree of hemolysis [5]. Mainly the ferritin rise due do hemolysis occurs in chronic hemolysis. But in our patient, it was mainly an EBV induced acute hemolysis, which occurred within 2 weeks. On top of this, research states that with an EBV infection itself, without hemolysis there is a rise in ferritin as an acute phase reactant with an average of $431 \mathrm{ng} / \mathrm{ml}$ [4]. Our patient's serial values of serum ferritin gradually came to normal within 6 weeks with settling of the infection. Here what we emphasize is, in our patient, rise of serum ferritin was probably due to both hemolysis and as an acute phase response to the infection and nevertheless with or without hemolysis it's important to do a serum ferritin level as a biomarker if someone clinically suspects an EBV infection. Serum ferritin can also be high in EBV associated hemophagocytic lymphohistiocytosis (HLA), but in our patient HLA was unlikely to occur because she did not fulfill the criteria for the diagnosis of HLA.

It has been found that $90 \%$ patients with acute EBV infection have asymptomatic deranged liver function tests and $50-75 \%$ have splenomegaly as in our index case. When deranged liver functions occur with high serum ferritin, acute EBV infection is also an important cause to exclude with more common causes such as hemochromatosis [6]. In this patient there are two main possible causes for asymptomatic deranged liver functions. Epstein Barr infection itself can cause mild hepatic damage. Exact mechanism is not very well understood but likely involves the host immune response to EBV antigens as suggested by Liver biopsy demonstrating a sinusoidal infiltrate of mononuclear cells, mixed portal tract inflammatory infiltrate and mild hepatocyte ballooning and vacuolization [7]. Secondly high ferritin levels can also contribute to mild hepatic damage as in our patient.

In this patient, she had very high levels of lactate dehydrogenase (LDH). Cause for this can be multifactorial. It can be due to the hemolysis, hepatitis or proliferation of lymphoid cells. LDH is an enzyme, which catalyzes the conversion of lactate into pyruvic acid. It has five iso-enzymes. LDH 1 and 2 are mainly located in red blood cells; LDH 3 is mainly located in lymphocytes and LDH 5 mainly in the liver. It has been shown that serial measurements of LDH are useful when evaluating the response to treatment in hemolysis because LDH level decreases with reduction of the hemolysis rate [8]. Mygind $\mathrm{N}$ et.al has done serial measurements of aspartate transaminase (AST) and LDH levels in 36 patients with sero-positive IMN and was found to have $70 \%$ of them having high AST and all of them having high LDH 1,2 or 3 iso-enzymes, but only $35 \%$ had elevated LDH 5 iso-enzyme. Furthermore after 10 weeks of acute infection AST levels became normal, but even after 16 weeks $50 \%$ of patients had elevated LDH [9]. So elevated LDH levels in our patient should be mainly due to proliferation of lymphoid cells and hemolysis, and it demonstrates the usefulness of monitoring serial LDH values in her because after recovery of the acute hemolysis episode, if she persists having high LDH levels then this could be due to ongoing lymphoid proliferation and she might possess a high risk of a lymphoid neoplasms later in her life.

Furthermore, although blood transfusion is a lifesaving procedure, sometimes it can result in life threatening complications. So, blood transfusion should be done only if it's definitely indicated. Specially in a female who is in her child bearing age, as in our patient, transfusion can give rise to unwanted pregnancy related side effects such as hemolytic disease of new born (HDN). It has been found that majority of cases of HDN is due to non-Rh-D antibodies which has been sensitized by previous blood transfusions rather than sensitization due to previous pregnancies [10]. So, this shows the importance of conservative management of even a moderate anemia without blood transfusion in situations such as primary EBV infection.

We believe though, a rare manifestation, cold type autoimmune hemolytic anemia should be considered in infectious mononucleosis patients who are presenting with anemia. This case report highlights the importance of conservative management of anemia secondary to EBV infection specially in a child bearing age female, and also the value of serum ferritin as an initial biomarker since usual biomarkers such as $C$ reactive protein levels remains within normal range during viral infections.

\section{Abbreviations}

AlHA: Auto Immune Hemolytic Anemia; ALT: Alanine Transaminase; AST: Aspartate Transaminase; CRP: C Reactive Protein; EBV: Epstein Barr Virus; HDN: hemolytic Disease of Newborn; HLA: Haemophagocytic LymphoHistiocytosis; IMN: Infectious Mononucleosis; LDH: Lactate Dehydrogenase; RBC: Red Blood Cell; VCA: Viral Capsid Antigen

\section{Acknowledgements}

Not applicable.

Funding

None. 


\section{Availability of data and materials}

Data sharing is not applicable to this article as no datasets were generated or analyzed during the current study. All data contained within the article.

\section{Authors' contributions}

CD preparation of manuscript and corresponding author. CP proof reading of manuscript. WC, SS gathering data of index case. DT, AA contributes for preparation of manuscript. DR contributes for arranging hematological investigations. UW, SW contributes for preparation of manuscript. RS clinical decision making and final proof reading of manuscript. All authors read and accepted the final manuscript.

\section{Ethics approval and consent to participate}

Not applicable.

\section{Consent for publication}

Informed written consent was obtained from the patient as well as next of kin (mother) of this patient for publication of this case report.

\section{Competing interests}

The authors declare that they have no competing interests.

\section{Publisher's Note}

Springer Nature remains neutral with regard to jurisdictional claims in published maps and institutional affiliations.

\section{Author details}

'Sri Jayawardanapura General Hospital, Thalapathpitiya, Nugegoda, Western province, Sri Lanka. ${ }^{2}$ Colombo South Teaching Hospital, Kalubowila, Dehiwala, Western province, Sri Lanka.

Received: 15 March 2018 Accepted: 11 January 2019

Published online: 18 January 2019

\section{References}

1. Cold agglutinin disease - UpToDate [Internet]. [cited 2018 Nov 27]. Available from: https://www.uptodate.com/contents/cold-agglutinin-disease

2. Malhotra V, Abraham T, Vesona J, Chopra A, Radakrishna N. Infectious mononucleosis with secondary cold agglutinin disease causing autoimmune haemolytic anaemia. BMJ Case Rep [Internet]. 2009 [cited 2018 Nov 27];2009. Available from: http://www.ncbi.nlm.nih.gov/pubmed/ 21894246

3. Karunarathne $S$, Weerasinghe $S$, Govindapala D, Fernando $H$, Jayaratne B. Cold autoimmune haemolytic anaemia secondary to Epstein Barr virus infection presenting with peripheral gangrene; case report. Thromb J [Internet]. 2012 Apr 18 [cited 2018 Nov 27];10(1):4. Available from: http:// www.ncbi.n/m.nih.gov/pubmed/22513360

4. van de Veerdonk FL, Wever PC, Hermans MHA, Fijnheer R, Joosten LAB, van der Meer JWM, et al. IL-18 Serum Concentration Is Markedly Elevated in Acute EBV Infection and Can Serve as a Marker for Disease Severity. J Infect Dis [Internet]. 2012 Jul 15 [cited 2018 Nov 27];206(2):197-201. Available from: https://doi.org/10.1093/infdis/jis335

5. Brabec V, Cermák J, Sebestík V. Serum ferritin in patients with various haemolytic disorders. Folia Haematol Int Mag Klin Morphol Blutforsch [Internet]. 1990 [cited 2018 Nov 27];117(2):219-27. Available from: http:// www.ncbi.nlm.nih.gov/pubmed/1697823

6. Thoufeeq MH, Ali Khan SL, Jain SK, Al-Shakerchi H, Hussain M. A case of acute infectious mononucleosis presenting with very high ferritin. World J Gastroenterol [Internet]. 2007 Jan 28 [cited 2018 Nov 27];13(4):637-8. Available from: http://www.ncbi.n/m.nih.gov/pubmed/17278235

7. Talwani R, Gilliam BL, Howell C. Infectious diseases and the liver. Clin Liver Dis [Internet]. 2011 Feb [cited 2018 Dec 27];15(1):111-30. Available from: http://www.ncbi.nlm.nih.gov/pubmed/21111996

8. Barcellini W, Fattizzo B. Clinical Applications of Hemolytic Markers in the Differential Diagnosis and Management of Hemolytic Anemia. Dis Markers [Internet]. 2015 Dec 27 [cited 2018 Nov 27];2015:1-7. Available from: http:// www.hindawi.com/journals/dm/2015/635670/.

9. Mygind N. Serial serum enzyme studies in infectious mononucleosis. Scand J Infect Dis [Internet]. 1976 [cited 2018 Nov 27];8(3):139-42. Available from: http://www.ncbi.nlm.nih.gov/pubmed/968455
10. Dajak S, Culić S, Stefanović V, Lukačević J. Relationship between previous maternal transfusions and haemolytic disease of the foetus and newborn mediated by non-RhD antibodies. Blood Transfus [Internet]. 2013 Oct [cited 2018 Nov 27];11(4):528-32. Available from: http://www.ncbi.nlm.nih.gov/ pubmed/23522892

\section{Ready to submit your research? Choose BMC and benefit from:}

- fast, convenient online submission

- thorough peer review by experienced researchers in your field

- rapid publication on acceptance

- support for research data, including large and complex data types

- gold Open Access which fosters wider collaboration and increased citations

- maximum visibility for your research: over $100 \mathrm{M}$ website views per year

At BMC, research is always in progress.

Learn more biomedcentral.com/submissions 